\title{
Expression of oestrogen receptor $\alpha$ and $\beta$ in rat heart: role of local oestrogen synthesis
}

\author{
Christian Grohé, Stefan Kahlert, Kerstin Löbbert and Hans Vetter
}

Medizinische Universitäts-Poliklinik, University of Bonn, 53111 Bonn, Germany

(Requests for offprints should be addressed to Christian Grohé)

\begin{abstract}
The role of cardiac oestrogen receptor expression and local oestrogen synthesis in the pathogenesis of cardiovascular disease is poorly understood. Therefore we studied the effects of the oestrogen precursors androstendione and testosterone on the expression of cyp450 aromatase, oestrogen receptor $\alpha$ and $\beta$, and inducible NO synthase (iNOS) in neonatal rat cardiac myocytes. Here, we show that cyp 450 aromatase is expressed in cardiac myocytes and incubation of cardiac myocytes with
\end{abstract}

oestrogen precursors leads to sexual dimorphic transactivation of an oestrogen-responsive reporter plasmid. Furthermore, incubation with oestrogen precursors stimulated expression of oestrogen receptor $\alpha$ and $\beta$, and iNOS in a gender-specific fashion. These data suggest that local oestrogen biosynthesis of the heart is effective to activate oestrogen receptor $\alpha$ and $\beta$, and downstream target genes in a gender-based fashion and may therefore contribute to the beneficial effects of oestrogen in the pathogenesis of cardiovascular disease.

\section{Introduction}

A large array of cardiovascular diseases such as cardiac hypertrophy or cardiac remodeling after myocardial infarction reveal significant gender-based differences (Dahlberg et al. 1990, Gardin et al.et al. 1995, Marcus et al. 1994). In this context, the changes of oestrogen plasma levels during the course of life have been attributed to play a role in the pathogenesis of this process. Although recent studies demonstrate that the heart is a target organ for oestrogen (Cabral et al. 1988, Malhotra et al. 1990, Grohé et al. 1996), the precise mechanisms whereby oestrogen may modulate cardiac hypertrophy and remodeling remain unclear. Previously, we have shown that cardiac myocytes and cardiac fibroblasts contain functional oestrogen receptors (Grohé $e t$ al. 1994, Grohé et al. 1997). Furthermore the cloning of a second oestrogen receptor type beta (Kuiper et al. 1996) and its expression in adult rat heart (Saunders et al. 1997) underline the importance of potential oestrogenic effects in the cardiovascular system. Recent observations suggest that local oestrogen synthesis may play an important role in the regulation of these effects seen in target tissues (Hickey et al. 1990). Local oestrogen biosynthesis requires the presence of the aromatase cyp 450 enzyme, which metabolizes $C_{19}$ steroids such as androstendione and testosterone to oestrogen by aromatization. Therefore, we sought to determine the expression pattern of cyp450 aromatase in cardiac myocytes and if the presence of oestrogen precursors such as androstendione and testosterone induces oestrogen receptor $\alpha$ and $\beta$ expression. Previously, the constitutive isoform and the endothelial NO synthase have been identified as oestrogenic downstream target genes in the myocardium (Weiner et al.
1994). To further characterize the role of NO synthases in cardiac myocytes, we investigated if the inducible isoform of the NO synthase is also oestrogen-responsive in cardiac myocytes and if oestrogen precursors such as androstendione and testosterone regulate the expression of this NO synthase isoform.

\section{Materials and Methods}

\section{Chemicals and solutions}

All chemicals were obtained from Merck (Darmstadt, Germany) if not otherwise specified.

\section{Cell culture techniques}

Cardiac myocytes from neonatal rat heart were prepared as described before (Grohé et al. 1997). Briefly, hearts of 1- to 2day-old rats (Wistar-Kyoto strain) were isolated and digested in eight consecutive steps (Simpson et al. 1982) after separation by gender. After each digestion, the medium containing the suspended cardiac cells was removed and an equal volume of Spinner/collagenase solution was added. The cardiac cell suspension was mixed with an equal volume of Ham's F10 (Gibco BRL; Eggenstein, Germany) supplemented with 10\% horse serum (HS; Biochrom; Berlin, Germany), $10 \%$ estrogen-free fetal calf serum (FCS; c.c.pro; Hamburg, Germany) and $25 \mu \mathrm{g} / \mathrm{ml}$ Gentamicin (Gibco BRL; Eggenstein, Germany) and stored at $4 \mathrm{C}$. Heart tissue was digested until the cells were completely suspended.

Suspensions were centrifuged at $400 \mathrm{~g}$ for $5 \mathrm{~min}$ and the cell pellets were resuspended in $20 \mathrm{ml}$ Ham's F10 supplemented with 10\% HS and 10\% FCS and plated on culture dishes. After 75 min the medium which contained the 
cardiomyocyte fraction of the digested tissue was removed. The adherent fraction of the plated cells consisted of cardiac fibroblasts. The dishes were gently rinsed three times to remove remaining cardiomyocytes. Cardiomyocytes were counted in a Fuchs-Rosenthal chamber and seeded on culture dishes at a density of $3 \times 10^{4}$ cells $/ \mathrm{cm}^{2}$ for trans-fection. The cardiomyocyte culture contained $90-95 \%$ myocytes, as assessed by immunofluorescence staining with an antibody against troponin-t (CP05, Dianova; Hamburg, Germany; data not shown).

\section{Immunoblotting}

Lysates of neonatal cardiomyocytes ( $40 \mu \mathrm{g} / \mathrm{lane})$ were analyzed by SDS-PAGE in a $7.5 \%$ gel and transferred to a nitrocellulose membrane as described before (Grohé et al. 1997). Protein content was measured with a standard Bradford assay. Immunoblotting was performed with a polyclonal aromatase antibody (1:500) (Mendelson et al. 1985), (kind gift of Dr E R Simpson), iNOS antibody (Calbiochem, Bad Soden, Germany; 1:2000, specific for the iNOS isoform and not crossreacting with the two other known members of the NO synthase family) and the following commercially available antibodies for oestrogen receptor $\alpha$ and $\beta$ : monoclonal oestrogen receptor $\alpha$ antibody (Bio-mol, Hamburg, Germany, SRA-1000, 1:500) which was produced by immunization of BALB $\backslash C$ mice with a synthetic peptide comprising residues 287-300 (RAANLWPSPLMIKR) from the hinge region of the human oestrogen receptor $\alpha$; polyclonal oestrogen receptor $\beta$ antibody produced by immunization of New Zealand white rabbits with a synthetic peptide corresponding to the $\mathrm{C}$ terminal amino acid residues 467-485 (CSSTEDSKNK ESSQNLQSQ) of the rat oestrogen receptor $\beta$ (Dianova, Hamburg, Germany, PA1-310 1:500). Detection was performed with the Enhanced Chemiluminescence technique (ECL, Amersham). Densitometrical analysis of protein induction was performed on an Epson GT 8000-scanner with the analysis software ScanPak (Biometra, Göttingen, Germany).

\section{Transfection assay}

Neonatal rat cardiac myocytes were seeded at a density of $3 \times 10^{4}$ cells $/ \mathrm{cm}^{2}$ for transfection. Cells were transfected using a liposome-conjugated transfection technique according to the manufacturer's instructions (DOTAP; Boehringer-Mannheim, Germany). Cells were transfected with a constitutively expressed $\beta$-galactosidase plasmid (see below) and either ERE$L U C$ (containing three copies of the vitellogenin estrogenresponsive element driving expression of the Luciferase gene) or TK-LUC (the same plasmid as ERE-LUC but lacking the oestrogen responsive elements; kindly provided by $\mathrm{Dr} \mathrm{C}$ Glass). After $24 \mathrm{~h}$, the transfection medium was removed and cardiomyocytes were maintained in phenol red-free Ham'sF10 in the absence or presence of testosterone, androstendione and dihydrotestosterone (Sigma Chemicals; St Louis, MO,
USA) and/or 4OH-androstendione (CIBA-Geigy, Basel, Switzerland), a competitive inhibitor of aromatase activity. Phenol red-free medium was used throughout all experiments as phenol red is known to act as a weak estrogen (Berthois et al. 1986). An equal volume of vehicle alone $(0.1 \%$ ethanol) was added to control cells. Following $24 \mathrm{~h}$ of incubation in the experimental conditions, cells were harvested and luciferase activity was determined on a luminometer (C-Gem, Optocom 1) as described (DeWet et al. 1987). In a subset of each transfection series, cells were transfected with pL7RHGal (SV40 promoter including a nuclear localization signal driving the $\beta$-galactosidase cDNA).Transfection efficiency was determined by staining of the transfected cells. Cells were washed with phosphate buffered saline and then fixed in $0.5 \%$ glutaraldehyde for $10 \mathrm{~min}$ followed by three more washes. They were then incubated overnight at $37^{\circ} \mathrm{C}$ in a staining solution containing $15 \mathrm{mM} \quad \mathrm{K}_{3} \mathrm{Fe}(\mathrm{CN})_{6}, \quad 15 \mathrm{mM} \quad \mathrm{K}_{2} \mathrm{Fe}$ (CN) $6 \cdot 3 \mathrm{H}_{2} \mathrm{O}, 0.15 \mathrm{mM} \mathrm{MgCl}$, $1 \%$ DMSO and $1 \mathrm{mg} / \mathrm{ml} \mathrm{X-}$ Gal. Nuclei of cells stained for $\beta$-galactosidase activity were counted and the results of each luciferase determination were normalized for the transfection efficiency.

\section{Statistical analysis}

All reported values are mean \pm S.E.M. Statistical comparisons were made by Student's $t$-test. Statistical significance was assumed if a null hypothesis could be rejected at the $P<0.05$ level.

\section{Results}

To determine the presence of the aromatase cyp450 protein in neonatal cardiac myocytes, a series of immunoblot experiments was performed. Immunoblotting with a monoclonal aromatase antibody detected the $54 \mathrm{kD}$ aromatase protein in lysates derived from neonatal rat cardiomyocytes. The level of protein expression was low in lysates obtained from unstimulated cardiac myocytes. Incubation with $10^{-9} \mathrm{M}$ $17 \beta$-oestradiol for $24 \mathrm{~h}$ lead to a marked increase in the abundance of aromatase protein (Fig. 1a). Control experiments with lysates derived from adult rat ovary and kidney revealed a band of the expected size in ovarian tissue and no detectable band in kidney tissue. In control experiments in which the primary antibody was omitted no bands were detected (data not shown). These data demonstrate that cyp450 aromatase is present in cardiac myocytes.

After our previous demonstration that cardiac myocytes contain functional oestrogen receptors (Grohé et al. 1994) and that cardiac myocytes contain cyp450 aromatase protein, we assessed the functional competence of cardiac myocytes to synthesize oestrogen from serum precursors using transient transfection experiments with a well characterized oestrogenresponsive reporter plasmid, ERE-LUC (Glass et al. 1988) in cardiac myocytes obtained from neonatal male and female rat heart. 
(a)

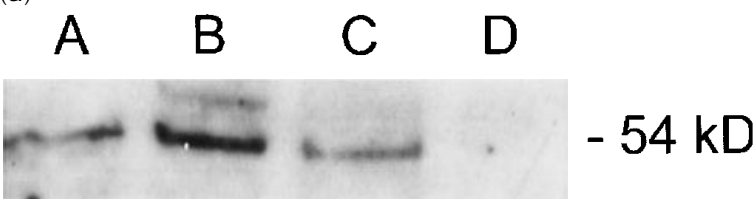

(b)

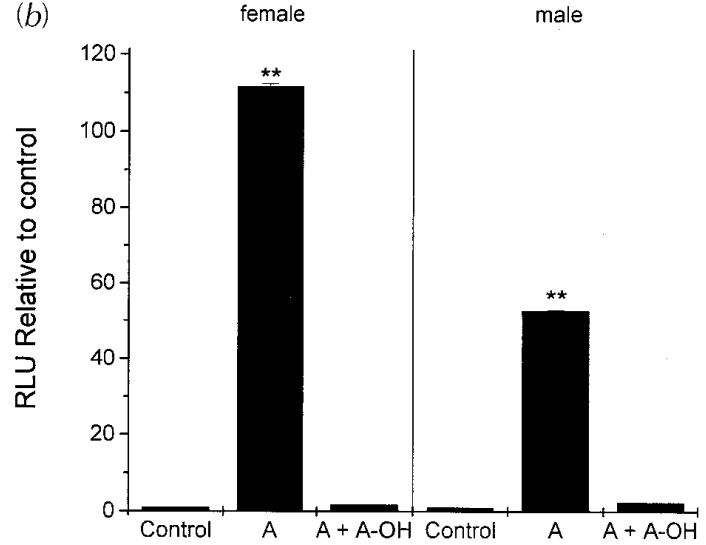

Figure 1 (a) Immunoblot analysis shows cyp450 aromatase protein in rat neonatal cardiac myocytes. Total cellular lysates of neonatal rat cardiac myocytes grown in the absence $(A)$ or presence $(B)$ of $10^{-9} \mathrm{M} 17$-oestradiol $\left(E_{2}\right)$ were subjected to SDS-PAGE, immunoblotted with an aromatase antibody, and visualized by a chemiluminescence technique. Note that the 54 $k D$ protein is detectable in the absence of $E_{2}$, but is more abundant following $E_{2}$ treatment. Lysates from ovary (C) and nephrogenic tissue (D) served as positive and negative controls respectively. One of three similar studies is shown. (b) Bar graph shows transactivation of an oestrogen-responsive reporter construct after incubation of rat neonatal cardiac myocytes with androstendione. Neonatal cardiac myocytes obtained from female and male rats were transfected with a reporter plasmid (ERE-LUC) in which an estrogen responsive element drives expression of the firefly luciferase gene. Cells were grown in the absence or presence of androstendione $(A)$ $\left(10^{-8} \mathrm{M}\right)$ or the aromatase inhibitor 4-OH-androstendione (A$\mathrm{OH})\left(10^{-7} \mathrm{M}\right)$ and harvested after $24 \mathrm{~h}$. Incubation with dihydrotestosterone $\left(10^{-8} \mathrm{M}\right)$, which cannot be converted to oestrogen served as a control (data not shown). Bars represent the mean luciferase activity with S.E.M. Luciferase activity is shown relative to control cells that were not exposed to hormones $\left({ }^{\star \star} P<0.01\right)$.

Unpassaged rat cardiomyocytes transfected with ERELUC showed transactivation of the reporter construct after incubation with androstendione $\left(10^{-8} \mathrm{M}\right)$ in cells derived from male and female animals (Fig. 1b) in the absence of oestrogen and serum in phenol red free medium (female: 111.7fold \pm 0.73 ; male: 52.7 -fold $\pm 0.27 ; n=9 ; P<0.01$ ). Testosterone also stimulated ERE-LUC activation with significantly higher values in female cells compared with male cells (female: 50.39-fold \pm 0.72 ; male: 20.22 -fold $\pm 1.01 ; n=9, P<0.01$ ) (Fig. 2). In contrast, the control plasmid lacking the oestrogen receptorresponsive element (TK-LUC) revealed no evidence of

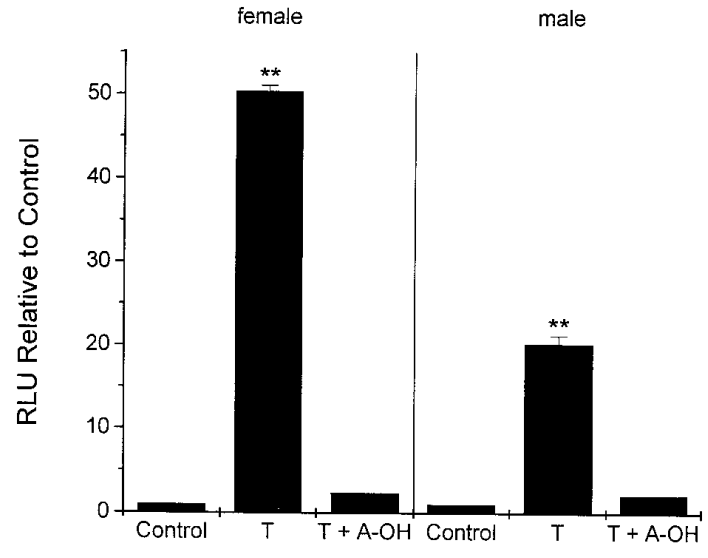

Figure 2 Bar graph shows transactivation of an oestrogenresponsive reporter construct after incubation of rat neonatal cardiac myocytes with testosterone. Neonatal cardiac myocytes obtained from female and male rats were transfected with a reporter plasmid (ERE-LUC) in which an oestrogen responsive element drives expression of the firefly luciferase gene. Cells were grown in the absence or presence of testosterone $\left(10^{-8} \mathrm{M}\right)$ $(\mathrm{T})$ or the aromatase inhibitor $4-\mathrm{OH}$ androstendione $\left(10^{-9} \mathrm{M}\right)(\mathrm{A}$ $\mathrm{OH})$ and harvested after $24 \mathrm{~h}$. Incubation with dihydrotestosterone $\left(10^{-9} \mathrm{M}\right)$, which cannot be converted to estrogen served as a control (data not shown). Bars represent the mean luciferase activity with S.E.M. Luciferase activity is shown relative to control cells that were not exposed to hormones $\left({ }^{\star \star} P<0.01\right)$.

hormonal induction (data not shown). Coincubation experiments with the specific aromatase inhibitor $4 \mathrm{OH}$-androstendione, when added to the experimental media, showed an inhibition of ERE-LUC activation by oestrogen precursors therefore demonstrating that aromatization is required to induce the oestrogen-responsive reporter plasmid. To further specify that the activation of ERE-LUC is mediated by aromatization of oestrogen precursors to oestrogen in cardiac myocytes, coincubation experiments with dihydrotestosterone, another product of androstendione and testosterone metabolism, which will not be converted to oestrogen were carried out. Incubation with dihydrotestosterone did not activate the oestrogen-responsive reporter plasmid. Control experiments with the oestrogen receptor antagonist ICI 182,780 completely inhibited the activation of ERE-LUC after incubation with oestrogen precursors (data not shown).

A series of immunoblot analysis was performed to study the effects of oestrogen precursors on endogenous cardiac genes. Western blot analysis with a specific monoclonal oestrogen receptor antibody detected the $66 \mathrm{kD}$ oestrogen receptor $\alpha$ protein in lysates derived from neonatal cardiomyocytes obtained from female and rat cardiac myocytes (Fig. 3a). Although the level of protein expression in the absence of incubation with oestrogen precursors $\left(10^{-9} \mathrm{M}\right)$ was low, incubation with androstendione (female: 25.2-fold; male: 8.0 fold; $n=3, P<0.05$ ) and testosterone (female: 35.7 -fold; male: 17.43-fold; $n=3, P<0.05$ ), for $24 \mathrm{~h}$ lead to a marked increase in 

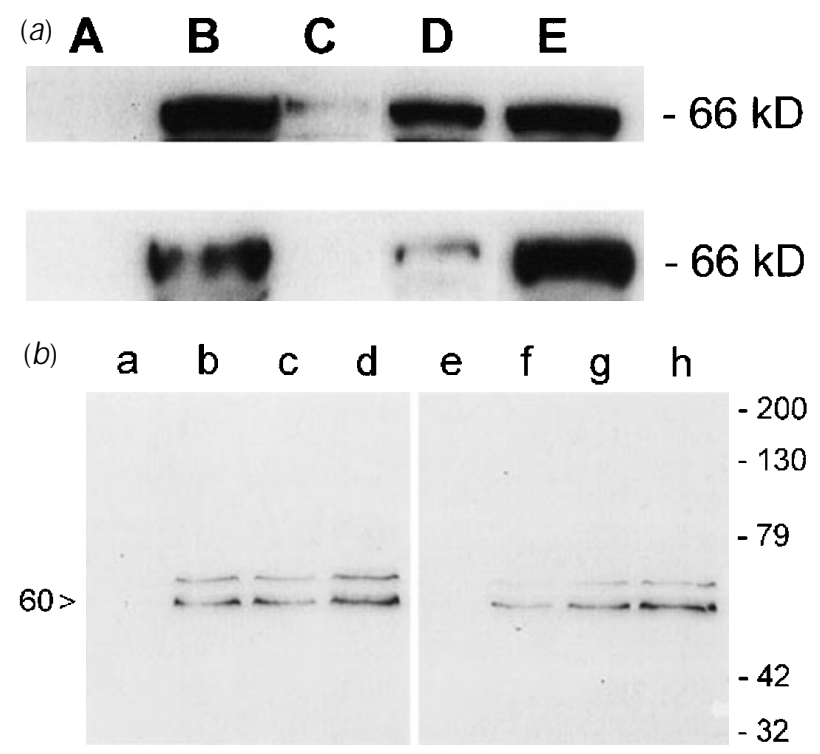

Figure 3 (a) Immunoblot shows activation of oestrogen receptor alpha expression by androstendione and testosterone. Total cellular lysates of male and female cardiac myocytes grown in the absence $(\mathrm{A})$ or presence of $10^{-9} \mathrm{M}$ testosterone (upper panel) or androstendione (lower panel) were subjected to SDSPAGE, immunoblotted with an anti-oestrogen receptor alpha antibody, and developed with a chemiluminescence technique. The $66 \mathrm{kD}$ estrogen receptor $(\mathrm{ER} \alpha)$ protein migrated as indicated. Incubation with testosterone induced a 35.7-fold increase in cells of female (B) and a 17.4-fold increase in cells of male (D) origin. Incubation with androstendione induced a 25.2-fold increase in cells of female (B) and an 8.0-fold increase in cells of male (D) origin. Coincubation with the anti-estrogen $\mathrm{ICl} 182780$ inhibited receptor induction (C). Lysate from adult rat ovary served as a positive control (E). One of three similar studies is shown. (b) Immunoblot shows activation of oestrogen receptor beta expression in neonatal rat cardiomyocytes by androstendione and testosterone. Total cellular lysates of female (left panel) and male (right panel) cardiac myocytes grown in the absence $(a, e)$ or presence $(b, f)$ of $10^{-9} \mathrm{M} 17 \beta$-oestradiol, testosterone $(c, g)$ or androstendione $(d, h)$ were subjected to SDSPAGE, immunoblotted with an anti-oestrogen receptor beta antibody, and developed with a chemiluminescence technique. The $60 \mathrm{kD}$ estrogen receptor (ER $\beta$ ) protein migrated as indicated. Incubation with testosterone induced a 12.4-fold increase in cells of female and an 11.4-fold increase in cells of male origin. Incubation with androstendione induced a 10.2-fold increase in cells of female and a 7.6-fold increase in cells of male origin. Coincubation with the anti-estrogen $\mathrm{ICl} 182780$ inhibited receptor induction and lysate from adult rat ovary served as a positive control (data not shown). One of three similar studies is shown.

the abundance of oestrogen receptor $\alpha$ protein. Coincubation with an oestrogen receptor antagonist (ICI 182,780) inhibited the activation of the oestrogen receptor $\alpha$ protein after incubation with oestrogen precursors. Furthermore, a series of immunoblot analysis was carried out to determine the expression pattern of the oestrogen receptor in rat neonatal cardiomyocytes. Again, the level of expression of the receptor protein was low in the absence of oestrogen, incubation with androstendione (female: 10.2-fold; male: 7.6-fold; $n=3$, $P<0.05$ ) and testosterone (female: 12.4-fold; male: 11.4-fold; $n=3, P<0.05$ ), for $24 \mathrm{~h}$ lead to a marked increase in the abundance of oestrogen receptor protein. In contrast to the findings of oestrogen receptor $\alpha$ expression in cardiomyocytes, no significant gender-based difference was found in the expression pattern of oestrogen receptor $\beta$ in neonatal rat cardiomyocytes. Lysates from adult rat ovary served as a positive control. In control experiments in which the primary antibody was omitted no proteins were detected (data not shown).

To determine whether oestrogen, besides its potential to upregulate the expression of the oestrogen receptor $\alpha$ and $\beta$, regulates the expression of downstream target genes, we assessed the level of the inducible NO synthase protein in male and female cardiomyocytes in the absence and presence of androstendione and testosterone. Immunoblot analysis of lysates from rat neonatal cardiomyocytes grown in the presence of androstendione and testosterone $\left(10^{-9} \mathrm{M}\right)$ identified a band with a molecular weight of $130 \mathrm{kD}$ (Figure 4), corresponding to the expected size of the known isoform of the iNO synthase (Weiner et al. 1994). In the absence of oestrogen precursors only a weak signal was detected. Incubation with androstendione (female: 12.5-fold, male: 12.2-fold; $n=3$, $P<0.05$ ) and testosterone (female: 3.7-fold, male: 2.9-fold; $n=3, P<0.05$ ), for $24 \mathrm{~h}$ lead to a marked increase in the abundance of iNOS protein. Again, coincubation with an oestrogen receptor antagonist (ICI 182,780) inhibited the activation of iNOS protein expression after incubation with oestrogen precursors. Lysates from adult rat ovary served as a positive control. Control experiments in which the primary antibody was omitted were negative (data not shown).

\section{Discussion}

Oestrogen has been attributed to play an important role in the modulation of cardiac hypertrophy and cardiac remodeling after myocardial infarction as observations from clinical studies and experimental data from animal models suggest (Scheuer et al. 1987, Nabulsi et al. 1993, Marcus et al. 1994, Mendelsohn et al. 1994). These studies implicate that oestrogen may participate in attenuation of cardiac hypertrophy (Cabral et al. 1988) and contractile function (Scheuer et al. 1987). The steroid hormone family of oestrogens consist of a large array of different metabolites, which display significant differences in their plasma levels before and after the menopause. However, all oestrogen metabolites are synthesized by aromatization of $\mathrm{C}_{19}$ steroids such as androstendione and testosterone. We have previously shown that cardiomyocytes and myogenic cells contain functional oestrogen receptors (Grohé et al. 1994, Kahlert et al. 1997) and activate downstream target genes like c-fos, egr-1 and connexin 43 


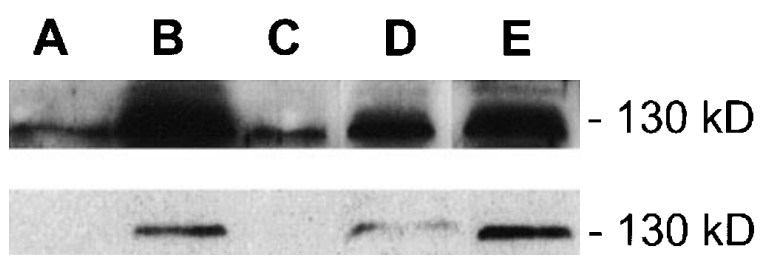

Figure $\mathbf{4}$ Immunoblot shows activation of inducible NO synthase expression by androstendione and testosterone. Total cellular lysates of male and female cardiac myocytes grown in the absence (A) or presence of $10^{-9} \mathrm{M}$ testosterone (upper panel) or androstendione (lower panel) were subjected to SDS-PAGE, immunoblotted with an anti-NO synthase antibody, and developed with a chemiluminescence technique. The $130 \mathrm{kD}$ iNO synthase protein migrated as indicated. Incubation with testosterone induced a 3.72-fold increase in cells of female (B) and a 2.9-fold increase in celis of male (D) origin. Incubation with androstendione induced a 12.5 -fold increase in cells of female and a 12.2-fold increease in cells of male origin. Coincubation with the anti-estrogen $\mathrm{ICI} 182780$ inhibited iNOS protein induction (C). Lysate from adult rat ovary served as a positive control (D). One of three similar studies is shown.

(Grohé et al. 1996). The recent cloning of a second oestrogen receptor (ER) called ER $\beta$ added another potential regulatory mechanism to explain the effects of oestrogen on the heart (Kuiper et al. 1996, Kuiper et al. 1997).

To further characterize the role of oestrogen in cardiovascular disease, we undertook this study to investigate if local oestrogen biosynthesis by aromatization of andro-stendione and testosterone may modulate oestrogen receptor expression and activation of oestrogenic downstream target genes in cardiac myocytes. In a first step, we studied the expression pattern of cyp 450 aromatase in cardiac myocytes. This enzyme is predominantly expressed in reproductive and adipose tissue and controls the local oestrogen synthesis before and after the menopause (Hickey et al. 1990, Simpson et al. 1994). We here show that cyp 450 aromatase, the enzyme which is responsible for the metabolism of $\mathrm{C}_{19}$ steroids to oestrogen is expressed in cardiac myocytes. In a next step, we investigated if cardiac myocytes can transactivate an oestrogen-receptor specific reporter plasmid in the presence of androstendione and testosterone in a gender-specific fashion. The transfection studies show that after incubation with oestrogen precursors, the reporter plasmid is activated in a gender-specific fashion and that incubation with andro-stendione leads to a signifcantly higher induction than testosterone. These data suggest that androstendione is metabolized to oestrogen to a higher degree than testosterone, as testosterone can also be metabolized to dihydrotestosterone by $5 \alpha$-reductase. The specificity of the transactivation of ERE-LUC by metabolized oestrogen precursors could be demonstrated as control experiments with an aromatase inhibitor (4-OH androstendione) and an oestrogen receptor antagonist (ICI 182780) showed an inhibition of the transactivation of ERE-LUC. In addition, incubation with dihydrotestosterone also yielded no activation of ERE-LUC. Taken together, these data demonstrate that oestrogen precursors can activate an oestrogen-responsive reporter in cardiac myocytes in a gender-based fashion.

Furthermore, we studied if the presence of oestrogen precursors might influence the expression of the oestrogen receptor in the heart. Ostrogen receptor $\alpha$ protein was induced in a gender-specific fashion with a significantly higher expression in female cardiac myocytes compared with lysates obtained from male cardiac myocytes at the same level of stimulation $\left(10^{-9} \mathrm{M}\right)$. These findings may be explained by the recent observation that transcriptional regulation of steroid hormone receptors are influenced by coactivators and repressors such as RAC3 or SRC, whose expression patterns may display significant gender differences. In contrast to the expression pattern of $E R \alpha$ which is influenced by gender, the expression of ER $\beta$ in cardiac myocytes revealed no sexual dimorphic pattern. Interestingly another protein of slightly lower molecular weight was detected in ER $\beta$ immunoblots. This may be explained by recent findings from Chu and Fuller (1997) who describe a new splicing variant of ER $\beta$ in different tisues including ovary. It may therefore well be that such splicing variants can also be detected in the heart and are part of the differential gene activation machinery. In the light of the observation that ER $\alpha$ and ER $\beta$ can form heterodimers to initiate transcription (Cowley et al. 1997) and display significant differences in their response to antiestrogens (Paech et al. 1997), these regulatory mechanisms may be helpful to explain the complex nature of oestrogenic effects. The dualspecific activation pattern of the two oestrogen receptors in the heart may help to explain gender-based differences found in cardiovascular disease.

Finally, we examined if oestrogen receptor activation stimulated by oestrogen precursors altered the expression pattern of the inducible NO synthase in the heart. The different isoforms of the NO synthase family have been shown to play an important role in cardiac physiology (Balligand \& Cannon 1997). The endothelial and the neuronal isoform have been shown to be induced upon stimulation by $17 \beta$-oestradiol in guinea pig heart on the mRNA level (Weiner et al. 1994, Hayashi et al. 1995). However, it remains controversial if the neuronal NO synthase is expressed in rat cardiac myocytes (Balligand \& Cannon 1997). We therefore hypothesized that the expression pattern of the inducible isoform may also be modulated by oestrogen in the myocardium. Here we show for the first time that iNOS expression is influenced by oestrogen in a gender-based fashion. In our hands, androstendione was a stronger stimulus than testosterone to upregulate iNOS expression in rat cardiac myocytes. These data add oestrogen to a large array of cytokines and inflammatory paracrine substances which have been shown to modulate iNOs expression. As the mechanisms whereby the different NO 
synthase isoforms and their inhibition modulate cardiovascular disease are currently under investigation (Hu et al. 1994, Hou et al. 1995), our data contribute to our understanding that the inducible form of the NO synthase family is influenced by oestrogen and possibly by the changing plasma levels of oestrogen and its precursors throughout life.

In summary, our findings that cardiac myocytes can synthesize oestrogen and activate downstream target genes upon stimulation by oestrogen precursors in a gender-based fashion may help to explain the complex mechanisms which regulate the gender-based differences found in many cardiovascular diseases such as cardiac hypertrophy and cardiac remodeling after myocardial infarction.

\section{Acknowledgements}

The authors would like to thank Dr ER Simpson for the aromatase antibody and Dr C Glass for plasmids TK-LUC and ERE-LUC. This work was supported by a grant from the Deutsche Forschungsgemeinschaft Gr729/4-1 and $\mathrm{Me}$ 1502/1-1.

The authors would also like to thank Dr A E Wakeling (Zeneca Pharmaceuticals, Cheshire, UK) for sharing the pure anti-estrogen ICI 182780 and Susan Fitzpatrick and Keith Parker for helpful discussions.

\section{References}

Balligand J-L \& Cannon PJ 1987 Nitric oxide synthases and cardiac muscle. Arteriosclerosis Thrombosis and Vascular Biology 17 1846-1858.

Berthois Y, Katzenellenbogen JA \& Katzenellenbogen BS 1986 Phenol red in tissue culture media is a weak estrogen: Implications cocerning the study of estrogen-responsive cells in culture. Proceedings of the National Academy of Sciences of the USA 83 2496-2500.

Cabral AM, Vasquez EC, Moyses MR \& Antonio A 1988 Sex hormone modulation of ventricular hypertrophy in sinoaortic denervated rats. Hypertension 11 193-197.

Chu S \& Fuller PJ 1997 Identification of a splice variant of the rat estrogen receptor $\beta$ gene. Molecular and Cellular Endocrinology 132 195-199.

Cowley SM, Hoare S, Mosselman S \& Parker MG 1997 Estrogen receptors $\alpha$ and $\beta$ form heterodimers on DNA. Journal of Biological Chemistry 272 19858-19862.

Dahlberg ST 1990 Gender difference in the risk factors for sudden cardiac death. Cardiology 77 (suppl 2) 31-40.

DeWet JR, Wood KV, DeLuca M, Helinski DR \& Subramani S 1987 Structure and expression in mammalian cells. Molecular and Cellular Biology 7 725-737.

Gardin JM, Wagenknecht L E, Anton-Culver H, Flack J, Gidding S, Jurosaki T, Wong N D \& Manolio TA 1995 Relationship of cardiovascular risk factors to echocardiographic left ventricular mass in healthy young black and white adult men and women. Circulation 92 380-387.

Glass CK, Holloway JM, Devary OV \& Rosenfeld MG 1988 The thyroid hormone receptor binds with opposite transcriptional effects to a common sequence motif in thyroid hormone and estrogen response elements. Cell 54 313-323.
Grohé C, Briesemeister G, Stimpel M, Karas RH, Vetter H \& Neyses L 1994 Cardiac myocytes contain functional estrogen receptors. Circulation 902898.

Grohé C, Kahlert S, Löbbert K, Meyer R, Linz K, Karas RH \& Vetter H 1996 Modulation of hypertensive heart disease by estrogen. Steroids 61 201-204.

Grohé C, Kahlert S, Löbbert K, van Eickels M, Stimpel M, Vetter H \& Neyses L 1997 Effects of moexiprilat on oestrogen-stimulated cardiac fibroblast growth. British Journal of Pharmacology 121 1350-1354.

Hayashi T, Yamada K, Esaki T, Kuzuya M, Satake S, Ishikawa T, Hidaka H \& Iguchi A 1995 Estrogen increases endothelial nitric oxide by a receptor-mediated system. Biochemical and Biophysical Research Communications 214(3) 847-855.

Hickey GT, Krasnow JS, Beattle W G \& Richards J 1990 Aromatase cytochrome $\mathrm{P} 450$ in rat ovarian granulosa cells before and after luteinization: adenosine 3', 5'-monophosph-dependent and independent regulation cloning and sequencing of rat aromatase cDNA and 5' genomic DNA. Molecular Endocrinology 4 3-12.

Hou JH, Kato H, Cohen RA, Chobanian AV \& Brecher P 1995 Angiotensin II-induced cardiac fibrosis in the rat is increased by chronic inhibition of nitric oxide synthase. Journal of Clinical Investigation $962469-2477$.

Hu L, Manning RD \& Brands MW 1994 Long-term cardiovascular role of nitric oxide in conscious rats. Hypertension 21 359-363.

Kahlert S, Grohé C, Karas RH, Löbbert K, Neyses L \& Vetter H 1997 Effects of estrogen on skeletal myoblast growth. Biochemical and Biophysical Research Communications 232 373-378.

Kuiper GGJM, Enmark E, Pelto-Hukko M, Haggblad J, Nilsson S \& Gustaffsson JA 1996 Cloning of a novel estrogen receptor expressed in rat prostrate. Proceedings of the National Academy of Sciences 93 5925-5930.

Kuiper GGJM, Carlsson B, Grandien K, Enmark E, Haggblad J, Nilsson S \& Gustaffsson JA 1997 Comparison of the ligand binding specificity and transcript tissue distribution of the estrogen receptor alpha and beta. Endocrinology 138 863-870.

Malhotra A, Buttrick P \& Scheuer J 1990 Effects of sex hormones on development of physiological and pathological cardiac hypertrophy in male and female rats. American Journal of Physiology 259 H866-H871.

Marcus R, Krause L, Weder AB, Dominguez-Mejia AN, Schork D \& Julius S 1994 Sex-specific determinants of increased left ventricular mass in the Tecumseh blood pressure study. Circulation 90 928-936.

Mendelsohn ME \& Karas RH 1994 Estrogen and the blood vessel wall. Current Opinions in Cardiology 9 619-626.

Mendelson CR, Wright EE, Porter JC, Evans CT \& Simpson ER1985 Preparation and chracterization of polyclonal and monoclonal antibodies against human aromatase cytochrome P-450 (P450arom) and their use in its purification. Archives of Biochemistry and Biophysics 243 480-491.

Nabulsi AA, Folsom AR, White A, Patsch W, Geiss G, Wu KK \& Szklo M 1993 Association of hormone-replacement therapy with various cardiovascular risk factors in postmenopausal women. New England Journal of Medicine 328 1069-1075.

Paech K, Webb P, Kuiper JM, Nilsson S, Gustafsson JA, Kushner PJ \& Scanlan TS 1997 Differential ligand activation of estrogen receptors ER $\alpha$ and ER $\beta$ at AP1 sites. Science 277 1508-1510.

Saunders PTK, Maguire SM, Gaughan J \& Millar MR 1997 Expression of oestrogen receptor beta $(E R \beta)$ in multiple rat tissues visualized by immunohistochemistry. Journal of Endocrinology 154 R13R16.

Scheuer J, Malhortra A, Schaible TF \& Capasso J 1987 Effects of gonadectomy and hormonal replacement on rat hearts. Circulation. Research 61 12-19. 
Simpson P \& Savion S 1982 Differentiation of rat myocytes in single cell cultures with and without proliferating nonmyocardial cells. Circulation Research 50 101-116.

Simpson ER, Mahendroo MS, Means GD, Kilgore MW, Hinshelwood MM, Graham-Lorence S, Amarneh B, Ito Y, Fisher CR, Michael MD, Mendelson CR \& Bulun SE 1994 Aromatase cytochrome P450, the enzyme responsible for estrogen biosynthesis. Endocrine Reviews 15 342-355.

Weiner CP, Lizasoain I, Baylis SA, Knowles RG \& Charles IG 1994 Induction of calcium-dependent nitric oxide synthases by sex hormones. Proceedings of the National Academy of Sciences 91 $5212-5216$. 